Fordham University

Fordham Research Commons

2014

\title{
Protective Webs: Exploring a Role for School Social Workers on Behalf of Delinquent Youths
}

Lauri Goldkind

Follow this and additional works at: https://research.library.fordham.edu/gss_facultypubs

\section{Recommended Citation}

Goldkind, Lauri, "Protective Webs: Exploring a Role for School Social Workers on Behalf of Delinquent Youths" (2014). Social Service Faculty Publications. 16.

https://research.library.fordham.edu/gss_facultypubs/16

This Article is brought to you for free and open access by the Graduate School of Social Service at Fordham Research Commons. It has been accepted for inclusion in Social Service Faculty Publications by an authorized administrator of Fordham Research Commons. For more information, please contact considine@fordham.edu, bkilee@fordham.edu. 
This article was downloaded by: [American University Library]

On: 13 January 2015, At: 09: 08

Publisher: Routledge

Informa Ltd Registered in England and Wales Registered Number: 1072954 Registered office: Mortimer House, 37-41 Mortimer Street, London W1T 3J H, UK

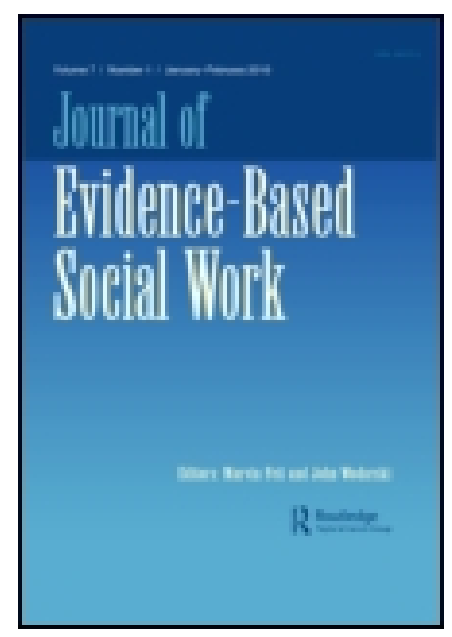

\title{
J ournal of Evidence-Based Social Work
}

Publication details, including instructions for authors and subscription information:

http:// www.tandfonline.com/loi/ webs20

\section{Protective Webs: Exploring a Role for School Social Workers on Behalf of Delinquent Youths}

\author{
Lauri Goldkind ${ }^{a}$ \\ a Graduate School of Social Service, Fordham University, New York, \\ New York, USA \\ Published online: 08 Aug 2014.
}

\section{CrossMark}

Click for updates

To cite this article: Lauri Goldkind (2014) Protective Webs: Exploring a Role for School Social Workers on Behalf of Delinquent Youths, J ournal of Evidence-Based Social Work, 11:4, 337-349, DOI: $10.1080 / 10911359.2014 .897103$

To link to this article: http:// dx. doi.org/ 10.1080/ 10911359.2014.897103

\section{PLEASE SCROLL DOWN FOR ARTICLE}

Taylor \& Francis makes every effort to ensure the accuracy of all the information (the "Content") contained in the publications on our platform. However, Taylor \& Francis, our agents, and our licensors make no representations or warranties whatsoever as to the accuracy, completeness, or suitability for any purpose of the Content. Any opinions and views expressed in this publication are the opinions and views of the authors, and are not the views of or endorsed by Taylor \& Francis. The accuracy of the Content should not be relied upon and should be independently verified with primary sources of information. Taylor and Francis shall not be liable for any losses, actions, claims, proceedings, demands, costs, expenses, damages, and other liabilities whatsoever or howsoever caused arising directly or indirectly in connection with, in relation to or arising out of the use of the Content.

This article may be used for research, teaching, and private study purposes. Any substantial or systematic reproduction, redistribution, reselling, loan, sub-licensing, systematic supply, or distribution in any form to anyone is expressly forbidden. Terms \& 


\title{
Protective Webs: Exploring a Role for School Social Workers on Behalf of Delinquent Youths
}

\author{
Lauri Goldkind \\ Graduate School of Social Service, Fordham University, New York, New York, USA
}

\begin{abstract}
Annually, 100,000 delinquent youths return to their communities from a detention facility and are required to attend a community school. School social workers may be best positioned to provide assistance with this transition; however, little is understood about how they are presently servicing this population. This study explores the interactions of school social workers and the advocacy and assistance they provide on behalf of juvenile justice youths. The author surveyed a national sample of current school social workers $(n=4,279)$ and reports on their involvement with juvenile justice, their work on behalf of the youths' families as well as their interagency collaborations.
\end{abstract}

Keywords: Juvenile justice youths, juvenile justice reentry, school social work, evidence-based practice

\section{INTRODUCTION}

Increasingly, social work practitioners in diverse practice settings are being asked to implement and evaluate evidence-based practices on behalf of their client populations. Indeed community alternatives and community-based sentencing are a key evidenced-based intervention strategy in the juvenile justice community. While home-based treatment models such as multi systemic therapy and other alternative to detention programs are being implemented across the country in an effort to reduce incarceration time for adolescents and youthful offenders, schooling and a delinquent's academic life are frequently overlooked when mapping the reentry landscape.

Little is understood about the interface between school social workers and youths reentering a school environment from the juvenile-justice system. Nevertheless, these professionals may be uniquely positioned to assist young offenders with this critical transition.

Nationally each year, approximately 100,000 youths are returning to their communities and engaging in the school reentry process (Nellis \& Wayman, 2009). Educational and juvenile justice scholars have identified a supportive school system as an accessible and reliable path toward promoting a healthy and productive future for youths released from juvenile detention settings (Bullis,Yovanoff, Mjueller, \& Havel, 2002; Stephens \& Arnette, 2000; Sullivan, 2004).

School social workers may be best positioned to serve as advocates and liaisons between a delinquent youth and the school. With their specialized training in relationship building and engagement, and their detailed knowledge of a community's assets and resources, school social workers can serve as allies in settings that may be unwelcoming or intimidating to juvenile justice

Address correspondence to Lauri Goldkind, Assistant Professor, Graduate School of Social Service, Fordham University, 113 West 60th Street, 716D, New York, NY 10023, USA. E-mail: goldkind@ fordham.edu 
youths and their families. As we consider evidence-informed and evidence-based reentry practices for juvenile justice youths, their academic environment cannot be overlooked. School is a critical institution in all young people's lives, possibly even more so for delinquent youths given mandate of school attendance and performance as a condition of remaining in the community. Given the chaotic lives and neighborhoods of many juvenile justice youths, school may be one of the most stable and nurturing settings in their lives.

The school reentry process for school-age ex-offenders is vitally important to their successful retention in their communities following time spent in a secure juvenile justice facility. Where many teachers and principals may be overwhelmed by the academic and social needs of justice youths, school social workers training in engaging challenged populations, their diagnosis, and assessment abilities as well as their ecological and contextualizing approach to working with individuals may position social workers as leaders for advocating for juvenile justice youths and their families in school settings.

\section{STUDY PURPOSE}

The purpose of this study is to begin to understand what role and services school social workers are providing for juvenile justice youths enrolled in their schools. There appears to be a gap in the school social work literature as to recommendations for practice and policy with this marginalized population of youths. Similarly, the juvenile justice reentry literature does not provide a further understanding of how the role of school as an institution or academic performance play in the lives of these young people. It is unclear whether this lack of knowledge and discourse is due to how schools categorize their students. Are the educational and supportive needs of juvenile justice youths thought of as similar to others in the school community/population, or is there a stigma associated with working with this population of youths in need of multi-systemic intervention?

\section{LITERATURE REVIEW}

Nearly 100,000 people under age 21 are released each year from correctional facilities in the United States (Snyder, 2004; Sickmund, Sladky, Kang, \& Puzzanchera, 2007). It is an imperative that these youths successfully re-enroll in and attend school. All of the oversight bodies with supervisory responsibility for justice youths demand school attendance, including judges, probation officers, after-care workers, and the school-based staff responsible for truancy prevention (Stephens \& Arnette, 2000; Balfanz, Spiridakis, Neild, \& Legters, 2003). School social workers may be positioned to help juvenile justice youths successfully transition back to community schools following an incarceration or detention event. There appears to be a lack of empirical research to better understand about how school social workers interact with and support these youths.

\section{Juvenile Justice Youths}

Snyder (2004) reports that the median time youths served in a facility was 17 weeks. For many youths, this will mean that more than a semester's worth of time is spent in detention. For approximately $10 \%$ of all committed youths, at least 70 weeks are lived in a correctional institution, creating the potential for a major disruption to their academic careers. Despite the federal commitment to reducing the disproportionate number of minority youths in custody, the young people involved in the juvenile justice system remain overwhelmingly children of color (Roscoe \& Morton, 1994; Lieber, 2002; Iguchi, Bell, Ramchand, \& Fain, 2005). 
Many juvenile justice youths come from homes where child abuse, foster care involvement, and other negative environmental factors are operating within the family system (Ryan, Herz, Hernandez, \& Marshall, 2007). There is a demonstrated link between familial abuse and juvenile delinquency. A study sponsored by the National Institute of Justice found childhood abuse or neglect increased the odds of juvenile delinquency by 59\% (Widom \& Maxfield, 2001). In addition, abused or neglected children were younger at the time of first arrest, committed twice as many offenses, and were arrested more frequently than children who had not been abused or neglected (Widom \& Maxfield, 2001; Stewart, Livingston, \& Dennison, 2008).

\section{School Issues}

Young people reentering their communities following custodial care in the justice system are required to go to school. Non-successful reintegration into the school environment may place these youths at greater risk of being remanded (returned to custodial care), dropping out of high school, and committing new crimes (Stephens \& Arnette, 2000; Bullis et al., 2002). Giles (2003) noted that traditional neighborhood schools frequently view these students as unnecessary burdens; are unprepared to enroll students at inconvenient times of year; and create inhospitable school environments for youths returning from custodial care.

Youths who have been placed in custodial care are significantly disadvantaged in comparison to their non-justice involved peers. Academically, they have lost time, credits, and continuity in terms of their school experience. Frequently the public school system re-enrolls them in the school where their justice troubles began, forcing the youths to attend school often with the victim of their original crime or attending school were adults may have a negative bias towards them based on pre-incarceration experiences (Stephens \& Arnette, 2000).

Justice-involved youths have consistently been shown to be behind their peers in academic achievement before and after their incarceration (Foley, 2001; Krezmein, Mulchay, \& Leone, 2008; Baltodano, Harris, and Rutherford, 2005). Foley reports that incarcerated youths appear to function within the below average to average levels of intelligence, and achievement of incarcerated youths has been consistently reported as 1 year to several years below expected grade levels.

Delinquent youths are also labeled as having special learning needs or requiring special education services at greater rates than their "non-delinquent" peers. Estimates of the number of youths within the U.S. juvenile justice system who have been diagnosed as having a 'disability' ranges from $30 \%$ to $60 \%$ of the entire juvenile justice population (e.g., Morgan, 1979; Rutherford et al., 1985; Murphy, 1986; Bullis \& Yovanoff, 2005; Baltodano et al., 2005; Quinn et al., 2005). A study focusing on the Virginia Department of Juvenile Justice reported that more than $40 \%$ of juveniles met special education criteria (McGarvey \& Waite, 2000). As the literature suggests, juvenile justice youths are operating with a paucity of academic assets, community assets, and family assets. School social workers are poised to bring tremendous value to the reentry process for these youngsters and their families.

\section{Building an Evidence-Informed Practice for School Social Workers}

There are over 14,000 school social workers practicing in schools across the United States (Franklin, 2005). A 2010 national survey of school social workers reveals a portrait of school social workers as overwhelmingly female $(88 \%)$, White $(78 \%)$, and licensed as school social workers credentialed (87\%; Kelly et al., 2010). In their sample, the vast majority of social workers were practicing in a public school context (89\%; Kelly et al., 2010). Additionally, it has been reported in this study that the population of school social work practitioners has not changed in over a decade and that the practice of school social work remains dominated by White, female professionals. 
Similar to most fields of practice in the social work discipline, increasingly school-based practitioners are being held accountable for "results" and outcomes documenting their successes. In addition to the monitoring of a range of professional behaviors and interventions, school social workers are also being asked to include research-based practices or evidenced-based practices in their repertoire (Franklin \& Kelly, 2009). However, recent research has indicated that despite having more resources and interventions to turn to, most school social workers rarely consult evidence-based practice resources like databases, scholarly journals, and books, preferring to rely on peer consultation and workshops as the primary method of informing their practice (Franklin \& Kelly, 2010; Kelly, 2008; Kelly et al., 2010).

\section{METHODS}

This exploratory study used an electronically delivered web-based survey design to collect data from a national sample of school social workers. The survey instrument was created based on the author's prior work investigating the role of school social workers in the school reentry process of juvenile justice youths as well as adapting content from the Teasley's School Social Worker Cultural Competence Questionnaire (2008).

\section{Survey Instrument}

The survey instrument asked school social workers to characterize their interactions and knowledge of juvenile justice youths enrolling in their schools as well as their knowledge of youth's involvement with the juvenile justice system; their work with juvenile justice youths' families; and their inter-agency work on behalf of juvenile justice youths as a sub-population of their regular school community. Additionally, respondents completed questions regarding the schools they work in and individual demographic characteristics. Sixteen questions focused specifically on respondents' caseloads, the percentage of justice-involved youths in their caseload, and their knowledge of young people's justice status; five questions focused on respondent's work with the families of justice-involved youths; and six questions focused on inter-agency collaboration and policy-level involvement on behalf of juvenile justice youths and their families. A listing of sample items may be found in Table 1.

\section{Data Collection}

Survey instruments were delivered electronically to participants via Questionpro.com. An initial e-mail introducing the project was sent by the investigator to the sample's e-mail accounts. E-mail invitations were sent in April of 2011. Respondents were offered the opportunity to receive a $\$ 5.00$ gift card incentive. This incentive was offered to the first 250 respondents. Two subsequent e-mail reminders were sent following the initial invitation. An additional reminder and request to participate was posted in the American Council of School Social Work e-mail newsletter. Responses to this survey were anonymous. The survey closed to new respondents on June 15, 2011.

\section{Sample}

A total of 4,279 school social workers were e-mailed an invitation to complete the survey including a link to the survey. These school social workers were members either of the School Social Work Association of America or the American Council of School Social Work. Administration from 
TABLE 1

Survey Questions

\begin{tabular}{ll}
\hline Area of Inquiry & Sample Question \\
\hline $\begin{array}{l}\text { Caseload: Direct service } \\
\text { to justice youth }\end{array}$ & What percentage of your regular caseload of students has been incarcerated? \\
In the past year, approximately how many students have reentered school with histories of \\
justice system involvement? \\
When are you informed that a student in your school has been arrested by the police? \\
How soon after being arrested are you informed of a student's arrest by police or \\
incarceration? \\
Are you involved in the enrollment process when a new student is returning from \\
incarceration in your school? \\
When working with a student who has been involved with the juvenile justice system, \\
which family members are most likely to interact with you? \\
How confident are you in assessing the strengths of the families of juvenile justice youth \\
enrolled in your school? (cooperativeness, supportive of their child, able to self \\
advocate, etc.) \\
How confidently are you able to describe the needs (family counseling, parenting training, \\
legal assistance, etc.) of juvenile justice youth and their families in your community? \\
To what extent, if at all, do you encourage the involvement of family members or \\
significant others when working with juvenile justice youth? \\
Do you attend school-based meetings (policy setting, community building, or other types) \\
that impact juvenile justice youth in your school? \\
Do you attend interagency coordination meetings that impact service delivery for juvenile \\
justice youth? \\
Are there meetings in your community of advocacy and service groups that might assist \\
juvenile justice youth and their families? \\
Does your school have linkages with colleges, universities, or research centers that provide \\
up to date information about juvenile justice youth and their families? \\
Interagency Collaboration
\end{tabular}

both organizations granted permission and promoted the survey to their memberships. This study was conducted with the approval of the investigator's Institutional Review Board. Eleven-hundred and twenty-seven individuals opened the survey link, 844 individuals began the survey, and 576 individuals completed a survey.

Respondents to the survey were primarily female (90\%) and ranged in age from 21 to 73 years of age; the average age was 43 years $(M=43.07, S D=11.05)$. Respondents had been working as school social workers for an average of 11 years $(M=11.11, S D=7.87)$, with a range between 1 and 38 years. Ninety-five percent $(94 \%)$ of the participants held an MSW. With regard to race, the sample was predominantly White $(80 \%)$ and included smaller contingents of African-American $(13 \%)$ and Hispanic (7\%). The demographic characteristics of this sample are comparable to those described by other national surveys of school social workers (Kelly, 2008; Astor, Behre, Wallace, \& Fravil, 1998).

With respect to region of the country, most of the respondents are from the Midwest (36\%), followed by the South (27\%), Northeast (20\%), and West (18\%). Currently, most of the respondents work in a suburban setting (41\%), but substantial minorities work in both urban (38\%) and rural (22\%) settings. High school (24\%), elementary school (19\%), and middle school (15\%) comprise the most prevalent placements followed by combinations of these three types of placements and other, smaller, and more specialized placements. School social workers in this sample are overwhelmingly situated in public schools (92\%). Table 2 further illustrates the demographic characteristics of the sample. 
TABLE 2

Demographic Characteristics

\begin{tabular}{|c|c|c|c|}
\hline & Frequency & $\%$ & Total \\
\hline \multicolumn{4}{|l|}{ Gender } \\
\hline Male & 51 & 10.4 & 491 \\
\hline Female & 440 & 89.6 & 491 \\
\hline \multicolumn{4}{|l|}{ Education } \\
\hline Bachelor's & 14 & 2.9 & 486 \\
\hline Master's & 460 & 94.7 & 486 \\
\hline $\mathrm{PhD}$ & 12 & 2.5 & 486 \\
\hline \multicolumn{4}{|l|}{ Race } \\
\hline White & 378 & 79.6 & 475 \\
\hline African American & 62 & 13.1 & 475 \\
\hline Latino & 35 & 7.4 & 475 \\
\hline \multicolumn{4}{|l|}{ Region } \\
\hline Northeast & 101 & 19.1 & 512 \\
\hline Midwest & 183 & 35.7 & 512 \\
\hline South & 137 & 26.8 & 512 \\
\hline West & 91 & 17.8 & 512 \\
\hline \multicolumn{4}{|l|}{ Locale } \\
\hline Rural & 110 & 21.7 & 508 \\
\hline Suburban & 206 & 40.6 & 508 \\
\hline Urban & 192 & 37.8 & 508 \\
\hline \multicolumn{4}{|l|}{ School Type } \\
\hline Elementary & 102 & 19.2 & 530 \\
\hline Middle School & 78 & 14.7 & 530 \\
\hline Middle/High School & 50 & 9.4 & 530 \\
\hline High School & 127 & 24.0 & 530 \\
\hline $\mathrm{K}-8$ & 43 & 8.1 & 530 \\
\hline $\mathrm{K}-12$ & 66 & 12.5 & 530 \\
\hline Other & 11 & 2.1 & 530 \\
\hline Multiple Sites & 39 & 7.4 & 530 \\
\hline District & 8 & 1.5 & 530 \\
\hline Early Childhood & 6 & 1.1 & 530 \\
\hline
\end{tabular}

\section{Juvenile Justice in the Schools}

The respondents were asked how many of the students whom they served in the past year were involved with the juvenile justice system. On average, nearly 12 students $(M=11.52)$ were reported to be juvenile justice students. It should be noted, however, that this variable exhibits considerable positive skew. Given that, a more reliable estimate of the "typical" number of juvenile justice students served per school social worker is provided by the median value rather than the mean value of this variable. Not surprisingly, the median is considerably lower $(\mathrm{mdn}=4.00)$.

The sample was also asked about the size of their "average" caseload. The responses to this question were, again, positively skewed again making the mean $(M=91.32)$ a less reliable estimate of this quantity than the median $(\mathrm{mdn}=40.00)$. Finally, the respondents were asked to provide an estimate of the percentage of their caseloads who were juvenile justice cases. Nearly $18 \%$ of the social workers' caseloads were reported to have "... delinquency or juvenile justice issues." Here, too, however, the responses to this question exhibited positive skew and, for that reason, the average percentage reported, again $18 \%$ is almost certainly an overestimate of this statistic. The median percentage of cases who were reported to be juvenile justice cases 
is $10 \%$. It is worth pointing out that this "global," or overall, estimate is compatible with another estimate of this same quantity that can be quasi-independently derived by taking the ratio of the median number of juvenile justice cases for the sample and dividing it by the median size of the social workers' caseloads: $(4 / 40)=10 \%$. It is clearly reassuring that these two estimates are in agreement. In addition, a truly independent estimate of the percentage of school social workers' caseloads that are composed of juvenile justice cases is available from the National Institute of Justice. That figure, again 10\%, conforms to the estimates derived herein and inspires confidence in the reliability of this statistic.

\section{Contextualizing the Juvenile Justice Caseload}

Having provided an estimate of the size, or magnitude, of the juvenile justice caseloads, it would be useful to learn more about how it is "distributed" in the schools that serve students involved in the juvenile justice system. To do that, we characterize the caseloads of the school social workers who participated in the survey in terms of a number of key demographic and background variables. Table 3 presents the median values of this variable by age, gender, race, locale, and region. Given the skewed distribution of the juvenile justice caseload variable, statistical significance tests for these demographic/background variable comparisons were conducted using the nonparametric analogs of the $t$-tests and one-way analyses variance (i.e., Mann-Whitney and Kruskal-Wallis tests). The findings from these tests indicate there are significant differences for three of the five demographic/background variables (i.e., gender, locale, and region: all, $p<.01$ ). More specifically, as seen in Table 3, the median size of the juvenile justice caseload is noticeably larger for male school social workers $(\mathrm{mdn}=.27)$ as compared to female school social workers $(\operatorname{mdn}=.10)$. With respect to locale, school social workers who work in suburban areas report significantly

TABLE 3

Juvenile Justice Caseloads by Selected Demographic and Background Variables

\begin{tabular}{lrll}
\hline & $N$ & $M$ & Total \\
\hline Age & & & \\
$23-35$ & 135 & .10 & 464 \\
$36-50$ & 188 & .11 & 464 \\
$\geq 51$ & 141 & .11 & 464 \\
Gender & & & \\
Male & 51 & .27 & 491 \\
Female & 440 & .10 & 491 \\
Race & & & \\
White & 378 & .10 & 475 \\
African American & 62 & .11 & 475 \\
Latino & 35 & .13 & 475 \\
Locale & & & 508 \\
Rural & 110 & .11 & 508 \\
Suburban & 206 & .07 & 508 \\
$\quad$ Urban & 192 & .11 & 512 \\
Region & & & 512 \\
Northeast & 101 & .05 & 512 \\
Midwest & 183 & .10 & 512 \\
South & 137 & .14 & .11 \\
West & 91 & & \\
\hline
\end{tabular}


different (i.e., smaller) median juvenile justice caseloads $(\operatorname{mdn}=.07)$ than their rural $(\mathrm{mdn}=$ $.11)$ and urban $(\mathrm{mdn}=.11)$ counterparts. Finally, with respect to region of the country, school social workers employed in the Northeast have significantly smaller juvenile justice caseloads than do their counterparts in all of the other regions of the country (i.e., the Midwest, the South, and the West).

\section{The Role of the School Social Worker with Juvenile Justice Students}

The survey respondents were asked a number of interrelated questions that sought to learn more about how school social workers are engaging with the students involved in the juvenile justice system, their families, and other institutional providers. These survey questions were submitted to a principal components analysis in order to "reduce" them to a smaller, more "fundamental" set of summary dimensions. The initial, unrestricted solution returned three summary dimensions that are presented in Table 4. This table presents the "pattern" matrix from this three-component solution. As indicated in this table, the first component references various events and behaviors that characterize the role of the school social worker in dealing with juvenile justice students. The second component characterizes the role of the school social worker in dealing with the various agencies that service these students. Finally, the third component addresses the role of the school social worker in working with the families of juvenile justice students.

Following the extraction of these three dimensions, the items that operationally define each dimension were submitted to internal consistency reliability analyses. The reliability coefficient (Cronbach alpha coefficient) for the first component is $(\alpha=) .85$; the second component is $(\alpha=)$.63; and the third component is $(\alpha=)$.67. These values suggest that the items on each of these subscales have adequate internal consistency and exceeded the recommended value of .70 (Nunnally, 1978). According to Schmitt (1996), in social science research, a correlation score above 0.70 is considered satisfactory.

Table 5 presents the descriptive statistics for each of these summary dimensions that have been operationalized as component-based scales. The items that define the first summary dimension have response scales that include the following response options: Never (1), Sometimes (2), Often

TABLE 4

Component Loadings

\begin{tabular}{|c|c|c|c|}
\hline & $\begin{array}{c}\text { Interactions } \\
\text { Directly } \\
\text { Impacting } \\
\text { Youths }\end{array}$ & $\begin{array}{c}\text { Interagency } \\
\text { Collaboration }\end{array}$ & $\begin{array}{c}\text { Interactions } \\
\text { with Youths } \\
\text { and Their } \\
\text { Families }\end{array}$ \\
\hline Knowledge of probation officer & .84 & & \\
\hline Informed when student enters detention & .80 & & \\
\hline Informed when reentering youth enrolls in school & .76 & & \\
\hline Involvement in enrollment process & .72 & & \\
\hline Informed when student arrested & .64 & & \\
\hline Collaborate with probation or parole & 63 & & \\
\hline Attend probation or parole meetings & & .87 & \\
\hline Attend interagency coordination meetings & & .75 & \\
\hline Attend policy setting meetings & & .69 & \\
\hline Assess strengths of juvenile justice youth and their families & & & .91 \\
\hline Describe needs of juvenile justice youth and their families & & & .82 \\
\hline Encourage family involvement & & & .52 \\
\hline
\end{tabular}


TABLE 5

Principal Components: Descriptive Statistics

\begin{tabular}{lccc}
\hline & $N$ & $\bar{x}$ & $S D$ \\
\hline Interactions directly impacting youths & 530 & 1.99 & .71 \\
Interagency collaboration & 500 & 2.10 & .87 \\
Interactions with youths and their families & 397 & 3.43 & .52 \\
\hline
\end{tabular}

(3), and Always (4). Referencing the numeric values assigned to these response options, the mean of the first summary dimension $(M=1.99, S D=71)$ indicates that, on average, school social workers "often" engage in the events and activities which define the first summary dimension. The response format of the items thaat define the second summary dimension include the following response options: Never (1), Very Infrequently (2), Sometimes (3), Frequently (4), and Regularly (5). Based on this response scale, the respondents indicate they are "sometimes" involved with the various agencies that are available to serve the juvenile justice population. Finally, the response format of the items used to define the "family" dimension also range from 1 to 4 with larger numbers indicating greater involvement by the school social worker with the families of the juvenile justice students. As seen in Table 5, the mean level of involvement with the families $(M=3.43, S D=.52)$ indicating school social workers' contact with the families of juvenile justice students ranges between "sometimes" and "frequently." Taken together, the mean levels of involvement of the respondents indicate that school social workers have fairly extensive contact with the juvenile justice students in their schools. This also seems to be the case regarding their involvement with the families of these students. However, based on their responses, school social workers report that they are somewhat less involved with the network of agencies that serve juvenile justice students $(M=2.10, S D=.87)$.

\section{Multivariate, Multiple Regression: Principal Components by Selected Demographic Predictors}

As was done with the juvenile justice caseloads variable, selected demographic variables were used as predictors or correlates of the three principal components. More specifically, age, gender, race, locale, and region were used as predictors of the student, agency, and family principal components. The multivariate statistical significance tests associated with each of these demographic predictors indicated that gender $(\mathrm{F}=3.57, d f=(3,316), p=.014)$, race $(\mathrm{F}=2.64, d f=(6,632), p=.015$, and locale $(\mathrm{F}=2.48, d f=(6,632), p=.022)$ were significantly related to (i.e., predictive of $)$ the set of three principal components, taken together. Visual inspection of the univariate significance tests indicated that gender was significantly related to both the student $(\mathrm{F}=8.55, d f=(1,318)$, $p=.004)$ and agency $(\mathrm{F}=6.04, d f=(1,318), p=.015)$ principal components. Race was significantly related to the family principal component $(\mathrm{F}=7.20, d f=(2,318), p=.001$. Finally, locale was significantly related to the agency principal component $(\mathrm{F}=5.44, d f=(2,318), p=$ $.005)$. Consistent with what was reported above regarding the juvenile justice caseloads, followup pairwise comparisons found that male school social workers were significantly more involved than female social workers with both juvenile justice students and the agencies that service this population. African American $(p=.002)$ and Hispanic $(p=.010)$ school social workers report greater involvement with the families of juvenile justice students than do their White counterparts. Finally, both rural $(p=.003)$ and urban $(p=.012)$ school social workers report significantly greater involvement with the agencies that service juvenile justice students than do suburban school social workers. 


\section{DISCUSSION}

The principal motivation for this study is to begin to put together an empirical foundation for the study of social work's involvement with the juvenile justice system. To this end, this investigation finds that of the three areas of primary contact with juvenile justice youths-direct contact, work with their families, and contact with the agencies that serve them-the first and second of these three areas receive the most attention from school social workers. Given the direct service role of the school social worker, it is not surprising that direct contact with these juveniles, followed by contact with their families and, last, contact with the agencies that serve them, are reflected in the relative frequencies/levels of involvement by school social workers. However, greater involvement by school social workers in any one of these three areas was also shown to have an association with greater involvement in either of the other two areas under investigation.

These findings are further elaborated by an examination of the demographic correlates of the juvenile justice caseloads of the social workers in the study sample. More specifically, three demographic variables were found to be significantly related to the juvenile justice caseloads of school social workers: (1) gender, (2) race, and (3) locale. With regard to gender, male social workers were found to be more involved in direct contact with juvenile offenders as well as with the social work agencies who supervise them after release. This may simply be reflective of the majority of juvenile offenders being male and possible comfort level of working with school social workers who are also males. As reported in this study, only $10 \%$ of all school social workers are males. Given that fact, it is not surprising, that juvenile justice cases are disproportionately assigned to male social workers (i.e., $27 \%$ of the caseloads of male social workers are juvenile justice cases whereas only $10 \%$ of the female social workers' caseloads include juvenile justice offenders). Precisely because most juvenile offenders are males and most school social workers are females, this "selection effect" may reflect some discomfort, or even "prejudice," which explains, at least partially, the disproportionate assignment of male juvenile offenders to male social workers.

With respect to the second statistically significant demographic (i.e., race), a similar selection effect might be operating. That is to say, this investigation found that both African American and Hispanic school social workers are more involved with the families of juveniles returning from the justice system than are their White counterparts. Again, this may reflect the fact that since most juvenile offenders are minorities; White school social workers possess some unconscious bias in dealing with their families as are school social workers of minority backgrounds. Given that most school social workers are both female and White, these findings are may not be particularly surprising.

Finally, with respect to the third demographic variable (i.e., locale: urban versus rural), we found that school social workers employed in suburban locales have significantly smaller juvenile justice caseloads than do their counterparts in either urban or rural locales. Most likely, this finding reflects the fact that there are relatively fewer minorities in the suburban areas of the Unites States.

Perhaps the most noteworthy single statistic to emerge from this study is an estimate of the proportion (or percentage) of school social workers' caseloads that involve students who have been in the juvenile justice system. This figure, $10 \%$, is, we feel, rather "robust" given that it is independently corroborated by the National Institute of Justice. Aside from having multiple estimates of this figure, the figure itself is important because it unambiguously "calibrates" the prevalence of juvenile offenders in the caseloads of school social workers. Although this figure waxes and wanes as a function of the demographic variables discussed above, on average, one of every ten students seen by school social workers is a juvenile offender. As the research literature suggests, our suspicion is that the vast majority of school social workers receive little or no training in working with this subpopulation of students. 


\section{Limitations}

This study offers a first look at the work by school social workers on behalf of juvenile justice youths and their families. While its findings represent a targeted exploration of how school social work practice interfaces with juvenile justice youths' school reentry experiences, several limitations should be noted. Specifically, the web-based data collection tool, the lack of standardized measures, as well as the absence of both a private and parochial school perspective are all limitations to consider when reviewing the findings of this study.

Esyenbach and Esyenbach (2004) note the biases that can result from web-based surveys (i.e., the non-representative nature of the Internet population) as well as the self-selection of participants (volunteer effect). Wyatt (2000) echoes similar concerns but along with Dillman (2011) suggests that the cost efficiencies coupled with the ease of implementation and execution make the use of electronic surveys compelling. This study marks the beginning of a heretofore unexamined, even neglected, area of study into the role school social workers and juvenile justice youths. While possibly limited due to the web-based survey design, the findings represent the first systematically available evidence that school social workers are, in fact, working with justice involved youths and a beginning description of what that work entails.

Given the lack of scholarship in this area, it is not surprising that standardized measures of school social workers' attitudes and involvement levels with juvenile justice youths are nonexistent. In addition to the lack of standardized measures, there is also a lack of foundational literature describing either the school reentry challenges of juvenile justice youths or the role that school social workers might play in helping juvenile offenders reenter school. This study's findings provide a point of departure for those interested in understanding how school social workers are interacting with juvenile justice youths in the school environment and what allied activities these social workers are engaging in (family involvement, interagency collaboration, etc).

Last, this study squarely focuses on the experiences of social workers situated in public school environments. Despite the endorsement of the two national school social work organizations, less than $10 \%$ of the respondents reported working in either a parochial or a private school setting. It is difficult to know how applicable the findings reported here are to social workers serving juvenile justice youths in private and parochial school settings.

\section{Implications and Future Directions}

This study describes the kinds of activities that school social workers engage in when serving juvenile justice youths. It further elaborates those findings by examining various demographic correlates of those activities and corroborates previous estimates of the prevalence of juvenile justice youths in the nation's schools. Still, much remains unknown. For example, as alluded to above, we know virtually nothing about the professional training and evidence practice behaviors, if any, that school social workers draw upon when working with juvenile justice youths. Moreover, we know virtually nothing about their effectiveness in dealing with the myriad difficultiespersonal and educational - that juvenile justice youths present. Stated somewhat differently, we need more "description" of the world of juvenile justice youths in our schools in addition to an "explanation" of the efficacy of school social workers in addressing their challenges. That is to say, juvenile justice youths, by the mere fact of being in the juvenile justice system, are almost certainly at a cumulative disadvantage relative to their counterparts. It should be perfectly obvious that time spent in the juvenile justice system is time not spent learning in a community school. This disadvantage can only be amplified in a world where the educational requirements for gainful employment are increasing at an exponential rate. Therefore, if school social workers are charged with helping to reduce, if not entirely eliminate, that ever-growing "gap," more "tools" will have 
to be placed at their disposal. In order to develop those tools, we simply have to know more about the challenges that they face.

\section{REFERENCES}

Astor, R. A., Behre, W. J., Wallace, J. M., \& Fravil, K. A. (1998). School social workers and school violence: Personal safety, training, and violence programs. Social Work, 43(3), 223-232.

Balfanz, R., Spiridakis, K., Neild, R. C., \& Legters, N. (2003). High-poverty secondary schools and the juvenile justice system: How neither helps the other and how that could change. New Directions for Youth Development, 99, 71-89.

Baltodano, H. M., Mather, S. R., \& Rutherford, R. B. (2005). Transition of incarcerated youth with disabilities across systems and into adulthood. Exceptionality, 13(2), 103-124.

Bullis, M., \& Yovanoff, P. (2005). More alike than different? Comparison of formerly incarcerated youth with and without disabilities. Journal of Child and Family Studies, 14(1), 127-139.

Bullis, M., Yovanoff, P., Mueller, G., \& Havel, E. (2002). Life on the "outs" examination of the facility to community transition of incarcerated youth. Exceptional Children, 69(1), 7-22.

Bureau of Labor Statistics. 2007. America's Youth at 19: School enrollment, training, and employment transitions between ages 18 and 19 summary. Washington, DC: U.S. Department of Labor. Retrieved from http://www.bls.gov/news.release/ pdf/nlsyth.pdf

Dillman, D. A. (2011). Mail and Internet surveys: The tailored design method-2007 Update with new Internet, visual, and mixed-mode guide. Hoboken, $\mathrm{NJ}$ : Wiley.

Eysenbach, G., \& Eysenbach, G. (2004). Improving the quality of Web surveys: The Checklist for Reporting Results of Internet E-Surveys. Journal of Medical Internet Research, 6(3), e34.

Foley, R. M. (2001). Academic characteristics of incarcerated youth and correctional educational programs: A literature review. Journal of Emotional and Behavioral Disorders, 9, 248-259.

Franklin, C. (2005). The future of school social work practice: Current trends and opportunities. Advances in Social Work, $6(1), 167-181$

Franklin, C., \& Kelly, M. S. (2009). Becoming evidence-informed in the real world of school social work practice. Children \& Schools, 31(1), 45-56.

Giles, D. R. (2003). School-related problems confronting New Jersey youth returning to local communities and schools from juvenile detention facilities and juvenile justice commission programs. Paper presented at The New Jersey Institute for Social Justice and the New Jersey Public Policy Research Institute's Reentry Roundtable Juvenile Reentry Session, Trenton, New Jersey.

Iguchi, M. Y., Bell, J., Ramchand, R. N., \& Fain, T. (2005). How criminal system racial disparities may translate into health disparities. Journal of Health Care for the Poor and Underserved, 16(4), 48-56.

Kelly, M. S. (2008). The domains and demands of school social work practice: A guide to working effectively with students, families and schools. Oxford, UK: Oxford University Press.

Kelly, M. S., Berzin, S. C., Frey, A., Alvarez, M., Shaffer, G., \& O’Brien, K. (2010). The state of school social work: Findings from the National School Social Work Survey. School Mental Health, 2(3), 132-141.

Krezmiem, M. P., Mulchay, C. A., \& Leone, P. E. (2008). Detained and committed youth: Examining differences in achievement, mental health needs, and special education status. Education \& Treatment of Children, 31(4), 445-464.

Leiber, M. J. (2002). Disproportionate minority confinement (DMC) of youth: An analysis of state and federal efforts to address the issue. Crime \& Delinquency, 48(1), 3-45.

McGarvey, E. L., \& Waite, D. (2000). Mental health needs among adolescents committed to the Virginia Department of Juvenile Justice, Developments in Mental Health Law, 20, 1-12.

Morgan, D. I. (1979). Prevalence and types of handicapping conditions found in juvenile correctional institutions: A national survey. The Journal of Special Education, 13(3), 283-295.

Murphy, D. M. (1986). The prevalence of handicapping conditions among juvenile delinquents. Remedial and Special Education, 7(3), 7-17.

Nellis, A., Wayman, R., \& Schirmer, S. (2009). Back on track: Supporting youth reentry from out-of-home placement to the community. Retrieved from http://www.sentencingproject.org/doc/publications/CC_youthreentryfall09report.pdf

Nunnally, J. C. (1978). Psychometric theory. New York, NY: McGraw-Hill Publishing Company.

Quinn, M. M., Osher, D. M., Poirier, J. M., Rutherford, R. B., \& Leone, P. E. (2005). Youth with disabilities in juvenile corrections: A national survey. Exceptional Children, 71(3), 339-345.

Roscoe, M., \& Morton, R. (1994). Disproportionate minority confinement. Retrieved from http://www.ncjrs.gov/txtfiles/ fs-9411.txt 
Rutherford, R. B., Nelson, C. M., \& Wolford, B. I. (1985). Special education in the most restrictive environment: Correctional/special education. The Journal of Special Education, 19(1), 59-71.

Ryan, J. P., Herz, D., Hernandez, P. M., \& Marshall, J. M. (2007). Maltreatment and delinquency: Investigating child welfare bias in juvenile justice processing. Children and Youth Services Review, 29(8), 1035-1050.

Schmitt, N. (1996). Uses and abuses of coefficient alpha. Psychological Assessment, 8(4), 350-353.

Sickmund, M., Sladky, T. J., Kang, W., \& Puzzanchera, C. (2007). Easy access to the census of juveniles in residential placement. Retrieved from http://ojjdp.ncjrs.gov/ojstatbb/ezacjrp/

Snyder, H. N. (2004). An empirical portrait of the youth reentry population. Youth Violence and Juvenile Justice, 2(1), 39-55.

Stephens, R. D., \& Arnette, J. L. (2000). From the courthouse to the schoolhouse: Making successful transitions. Washington, DC: U.S. Department of Justice, Office of Justice Programs, Office of Juvenile Justice and Delinquency Prevention.

Stewart, A., Livingston, M., \& Dennison, S. (2008). Transitions and turning points: Examining the links between child maltreatment and juvenile offending. Child Abuse \& Neglect, 32, 51-66.

Sullivan, M. L. (2004). Youth perspectives on the experience of reentry. Youth Violence and Juvenile Justice, 2(1), 56-71.

Widom, C. S., \& Maxfield, M. G. (2001). An update on the "Cycle of Violence." Washington, DC: National Institute of Justice. Retrieved from https://www.ncjrs.gov/txtfiles1/nij/184894.txt

Wyatt, J. C. (2000). When to use web-based surveys. Journal of the American Medical Informatics Association, 7(4), 426-430. 